\title{
SEMI-SUBSISTENCE FARMING SITUATION AND POLICY - THE EXAMPLE OF HUNGARY
}

\author{
C. Forgács \\ Corvinus University of Budapest
}

\begin{abstract}
In Hungary small farms have played very important role since collectivization (1959-61). Up to radical changes small households have received strong support from coops in the field of providing inputs on one side and, marketing their products on the other. The latter was disrupted by radical reforms and small farms started struggling with survival under market conditions. Government took measures to provide a development path for those having a chance to become competitive after five years development. Three calls (2004, 205 and 2006) were released. In Hungary SSF from three regions were more interested in getting the grant as North Great Plain, South Transdanubia and South Great Plain. All three regions are agriculture dominated ones. The policy with the call has reached a very moderate number of SSFs and, on the other side small farms, either because not meeting the criteria of the call or not wanted to take the additional costs of being registered and monitored for such a small amount of support decided not to apply. The paper ends with policy lessons.
\end{abstract}

Keywords: subsistence farms, semi-subsistence farms, small farms, CEE agriculture

\section{Introduction}

Different countries use different criteria for subsistence and semi-subsistence farms. Main stream approaches to the topic are connected with criteria such as: farm size, economic size and market participation.

To understand the Hungarian case we have to look at the concept of SF and SSF what Central Statistical Office (CSO) uses for definition. Carrying out a census for obtaining data from agricultural households CSO puts three questions for categorization. First, do you produce agricultural products for self supplying only (subsistence farms, SFs)? Second, do you sell products on the market that your family does not consume (semi-subsistence farms, SSFs)? Third, is your farm is a commercial oriented one (commercial oriented farms, $\mathrm{COFs}$ )? According to CSO definition all those households having at least one big animal (cattle, pig, horse etc.) or minimum as many as 25 poultry or minimum field of 1500 square meters for farming can be regarded as agricultural holding. Data on small farms are recorded in details by agricultural census once in a decade while data on small farms are collected by survey based on sampling between two census in order to follow structural changes and development.

The paper draws a picture of small farms' development since the beginning of the sixties of the last century. Existing small farms in the country goes back decades and since collectivization (1959-1961) it has been a characteristic of Hungarian large scale farm system. Following putting into force the new economic mechanism in Hungarian agriculture (1967) a process of integration between small and large farms and especially between small farms and cooperatives has been taken place. It is discussed how these integration brought economic advantages for both small and large farms. However, at the beginning of radical reforms it was a challenge for small farms to adjust the Common Agricultural Policy (CAP) following the country's joining the EU.

Taking ESU as indicator to find out how many SFs and SSFs are existing in the country CSO counts household as SSFs if their size is between ESU $1<2$ and SFs below ESU 1 while it is a commercial oriented one if ESU is between ESU $2<6$, however in the latter case a small part of produce may also be consumed by the family.

Concerning to support of small farms Ministry of Agriculture and Rural Development (MoARD) defined SSF farms eligible for a call between ESU $2<5$. MoARD fixed the minimum guideline for viable farms as ESU 2, meanwhile for some other EU programs (e.g. in Agroenvironmental Oprerative Program) 5 ESU was set as criteria to become eligible getting support under National Rural Development Plan (Hegyi J.-Kacz K.-Kettinger A. (3).

\section{Materials and methods}

In order to get a picture of small farms' development in the country an analysis will be carried out. The latter makes it possible to understand the development of small farms since early sixties of last century. The social and economic aspects of small farms will be highlighted and their struggling during transition be discussed. An analysis on measures to support small farms after EU eastward enlargement and the outcomes of measures is the essential part of the paper. 


\subsection{Historical background}

In Hungary SFs and SSFs have played very important role for decades. During collectivization (1959-1961) large number of cooperatives was organized and the coop subsector of agriculture produced some half of Gross Agricultural Output (GAO). Agricultural policy decided to allot small plots of 0,3-0,1 ha to cooperatives' members for household production (SF, SSF) as good incentive. Household farms produced mainly fruits, vegetables and animal products for the family and partly for the markets. Coop members also could use their labor force and that of family members on household production when no tasks were given in the coops.

To increase efficiency of national economy there was a need to introduce new economic mechanism into practice giving more freedom to enterprises and farms to fix their production structure under their objective function of maximizing profits.

\subsection{Developing integration between small farms and cooperatives (1967-1985)}

During the years following economic reform in 1967 for agriculture labor and capital intensive production (e.g. fruits, vegetable, pig) has been gradually moved to small scale farming and, branches offering the possibility to take the advantage of economic of scale and needed relatively less capital were kept in large farms (e.g. crop, poultry, beef production to a certain extent). The income disparity between people engaged in agriculture and in the rest of the economy was significant, and the channel of cooperation between coops and household production was used as one to provide additional income for coop members. Coops provided inputs for coop members mostly at costs level, while paid premium price for products produced by coop members' households and marketed by the coops and, other services to households were also offered by the coop. Coop members had to pay for inputs and services only after marketing the products.

In 1972 as many as 1.6 million small scale farms were in Hungary, some half of them belonged to coop members. Most of the second half of them meant farming around the house (kitchen gardens). The market share of small farms has become significant in some branches. E.g. it amounted to 60$80 \%$ of outputs of vegetable production, $50-60 \%$ of pig production. As far as the income distribution between small scale farming is concerned $36 \%$ went to peasant families, $25 \%$ to families with double income sources, $25 \%$ to workers and intellectual people and $14 \%$ to people where pension was the main source of income.

The development of household farming clearly showed producers are really interested in increasing output if, at the end of the day, they will be compensated by getting additional income. Small scale production (mostly coop members' households) had a share in GAO some one third since the seventies up to political reforms. In late eighties of last century more and more coops had severe financial difficulties so coop leaders decided to charge services towards members' households.

\subsection{Effect of the economic and agricultural reforms in the late 1980's early 1990's}

Hopes dealt with political turn were as follows: (a) part of national debt will be canceled and, (b) Hungary may become EU member until the middle of the 90s of the last century. None of these two expectations have happened. Instead, in compare with data of 1989 there was a decline of $20 \%$ in GDP and 30\% in GAO in 1993-1994. Standard of living reached the level of that in 1990 was achieved in 1999. At the beginning of 90s politicians had the vision of family farm model as the most desirable one for the country and should be focused by agricultural policy and as part of the policy large farm system started to break up.

Production type coops had to be reorganized and transferred to meet new legal needs. New coops were not obliged to provide members with jobs any more. In early $90 \mathrm{~s}$ some 1,4 million private agricultural holdings, mostly SFs and SSFs, were counted by CSO and they cultivated more than $50 \%$ of agricultural land. Dual character of Hungarian farm structure occurred similar to some other CEECs, but neither large, nor small farms dominated the sector in Hungary. In the late eighties, as part of the policy of previous years, those coop members and coop employees (1.6 million people) having no land were allotted $0.5-2$ ha land as ownership according to their coop shares. Another more than 1 million people got land back as original landowners or their descendants according to four laws passed on compensation (Table 1). The average land area of private agricultural holdings amounted to some 2.3-2.6 ha in early 90s.

After radical reforms COMECON (Council of Mutual Economic Assistance, CMEA) integration was collapsed

Table 1. Land distribution by eligible people due to compensation in Hungary in 1991

\begin{tabular}{|l|c|c|c|}
\hline \multicolumn{1}{|c|}{ Eligible people } & $\begin{array}{c}\text { Number of } \\
\text { people eligible }\end{array}$ & $\begin{array}{c}\text { Number } \\
\text { of land } \\
\text { parcels }\end{array}$ & $\begin{array}{c}\text { Average size } \\
\text { of parcels, } \\
\text { ha }\end{array}$ \\
\hline $\begin{array}{l}\text { Compensation to original } \\
\text { landowners }\end{array}$ & $1,040,000$ & 592,000 & 1.8 \\
\hline $\begin{array}{l}\text { Allotted land to those not } \\
\text { having land ownership } \\
\text { (coop members, and coop } \\
\text { employees) }\end{array}$ & $1,600,000$ & $3,000,000$ & 1.7 \\
\hline \\
Total
\end{tabular}

Source: Varga Gy. Presentation (2002) 
affecting Hungarian food exports substantially. Domestic food consumption went back by $20 \%$. Small farmers in general have severe difficulties to find markets for their products. Weakening households of coop members was less fast but it also started when coops decided to establish cooperation with members' household on market basis.

During the first decade of transition number of private holdings started declining steadily as farming has not been proved profitable. Number of individual farms amounted to only 958,5 thousands one decade after political turn. Their number increased due to compensation laws passed, but many new landowners at old age leaving in towns and cities or being retired were not interested in farming and decided not to cultivate the land but to lease it out or to sell it if, it was possible. However, over time the land use pattern showed a clear trend of concentration but not the land ownership. Small and medium size private holdings and large corporations (apart from some special cases practically only individuals can own land in Hungary) having not sufficient area for production wanted to rent more and more land.

Changes have affected small farms a great extent, meanwhile they have played an important role as part of the social net. Most of the difficulties of small scale farming can be generated from the quota system introduced, the delay to adjust to market needs and the assimetry in direct payments between farmers in NM states and those in EU 15. Number of private farms has been further decreasing since early nineties, still there were as many as 706,9 thousands in 2005, $73.3 \%$ with not more than one ha of UAA (Annex 2), indicating the low level of concentration by ESU in compare with selected EU 15 members.

Most of people loosing their job in rural areas especially due to breaking up coops had no chance to get a job out of agriculture, and the number of employees engaged in agriculture also went back from some 700 thousands at the beginning of 90 s to around 120 thousands in 2007 . For most of fired people the only way for surviving was to run SSF or at least SF. Among them there have been also ones having off farm job (full time or part time) besides part time farming. As the input costs of farming went up (prices were increased for chemicals, seeds, etc.) and small farms were not able to modernize the farm they had no other choice than giving up farming. Increasing number of people, mostly old pensioners started getting a standard of living below the poverty line. Unemployment level in agriculture dominated rural areas amounts to $30-35 \%$ but in some areas it reaches $50-70 \%$. All this happens when UAA amounts to $63 \%$ in Hungary while it is only $43 \%$ in EU.

\subsection{Socio-economic characteristics of SSFS}

In 2000 private holdings amounted to 958534 and were very much dominated by small farms having small parcel of land. $60.4 \%$ of private holdings produced for the family only. Another $31.5 \%$ of small farms were regarded as SSFs and only $8 \%$ individual farms (75-77000 farms) produced mainly for markets (COFs). Total land area of private holdings accounted a bit above $50 \%$ of agricultural land. Besides arable land, grassland and forests areas were the most important types of cultivation of land in 2005. $41.8 \%$ of holdings have no arable land at all. They mainly had animals around the house or some grass area, orchard, wine yards mostly in gardens. Another $30 \%$ of holdings have no more arable land than 0.5 ha. While less than $1 \%$ of private holdings, having arable land above 50 ha, cultivate more than $42 \%$ of arable land used by private holdings.

Average age of farmers and workers of private holdings has been increasing. In 2005 ratio of people above 54 years amounted to $52 \%$ in 2000 and that of people below 34 years increased and reached $8 \%$ in 2003. Concerning education of farmers not much change took place between 2000 and 2005. In 2005 people with college/university degree had a share of $2 \%$, and $6 \%$ of those obtained secondary school certificate. However $80 \%$ of farmers had only practical experience and were educated not higher than primary school. In average men were higher educated than women. In 2005 every second primary producer was a pensioner, employees amounted to $42 \%$. Full time farmers had a share of $61 \%$ with no significant change to previous years, $38 \%$ had full time job other than in agriculture. In two third of holdings there were 2-3 working people and, in $30 \%$ of holdings had only one worker.

\subsection{Survey on small farms}

According to Farm Structure Survey 2007 (FSS 2007) about 7400 agricultural enterprises were engaged in agriculture and nearly 619 thousand private holdings were carrying out agricultural activity not taking into account the noticeable agricultural production in kitchen gardens and holiday home gardens (CSO). Most of SFs (43.8\%) and two third of COFs were involved in crop production, while $45.6 \%$ of SSFs belonged to mixed type category (Figure 1). $48.2 \%$ of crop production and $77.8 \%$ of animal husbandry in private farms came from SFs .

Looking at the distribution of individual farms by EU regions SF was the leading on in all regions with very high share (around $60 \%$ ) in Central and West Transdanubia and in Central Hungary (Annex 6). In all regions except South Great Plane crop production has the highest share and mixed farms get second place except in Central Hungary Region. In South Great Plane the three types of farming is well balanced (Annex 7).

Between 2003 and 2007 decline of mixed cropping farms was around one third, that was more than $25 \%$ in case of other mixed farms. At the same time specialized farms went back less. Within the latter specialist grazing livestock indicates significant share $(20.5 \%)$, while specialist horticulture and specialist granivores decreased $(4.5 \%$ and $3.3 \%)$. Concerning the distribution of private holdings between different types the dominant ones were specialist granivores $(19.2 \%)$, mixed crops $(17.4 \%)$, specialist 
permanent crops (16.7\%) and mixed livestock holdings (16\%) in 2003. In 2007 specialist granivores extended their share to $23 \%$, special grazing livestock increased by $50 \%$ and, share of all other types except non-classifiable farms decreased. In 2003 SFs amounted to $79.2 \%$ and SSFs $8.9 \%$ of total private holdings and these figures in 2007 were $81.4 \%$ and $7,5 \%$ respectively. Number of total private holdings decreased from 2003 to 2007 more than the decline of SFs and less than that of SSFs (Annex 8 and 9). Especially people at old age living alone decided to quit their semisubsistence farming. The decline in SSFs exceeded that of total individual farms (Annex 10).

Based on MoARD SFs amounted to some 50\% more than that of SSFs, this ratio was around $400 \%$ in case of animal husbandry farms, concerning mixed farms SSFs exceeded SFs by two third. Commercial oriented private holdings amounted to $15.5 \%$ in 2005, much higher in SFs and less in SSFs (Table 2.)

Table 2. Breakdown of private agricultural holdings by goal of farming, 2005.

\begin{tabular}{|l|c|c|c|c|}
\hline \multirow{2}{*}{$\begin{array}{c}\text { Goal of } \\
\text { farming }\end{array}$} & Crop produc & Animal husb & Mixed & Total \\
\cline { 2 - 5 } & \multicolumn{4}{|c|}{$\%$} \\
\hline SF & 48.15 & 77.96 & 38.06 & 51.46 \\
\hline SSF & 29.73 & 19.18 & 47.55 & 33.06 \\
\hline $\begin{array}{l}\text { Commerc. } \\
\text { oriented }\end{array}$ & 22.12 & 2.86 & 14.39 & 15.48 \\
\hline Total & 100.00 & 100.00 & 100.00 & 100.00 \\
\hline
\end{tabular}

Source: MoARD, 2009

\subsection{Production orientation of SSF}

Value of GAO in private holdings, in average, amounted to HUF 525 thousands in 2000. This figure in holdings with mixed profile was almost double (HUF 914 thousands), while in farms with animal husbandry it accounted to only HUF 260 thousands. The picture was spreading by regions. Farms located in the Great Plane were above the average (especially in the South part of it, while figure of all other crop and mixed farms in all other regions were below the average level. Private farms with animal husbandry in West and South Transdanubia had better figures than the average.

Looking at farms by production goals the average GAO of commercial oriented holdings had a figure of HUF 2196 thousands, however, SSFs produced GAO as high as HUF 738 thousands and this figure in SFs accounted to only HUF 192 thousands. No data available on market share of SSFs. Generally it can be said that SSF sell their products on local producers' markets once a week, mostly on Saturday.

Willingness to cooperate, apart from long term cooperation between small producers within the village or town, especially in case of SSFs and SFs is not very high during the last two decades. Political propaganda against cooperation has been very strong in early nineties and this "brain wash" was rather efficient. Small farms trust themselves rather than in cooperation even if they have to pay a higher transaction costs.

Hungary has $7 \mathrm{EU}$ regions. Three are located in Transdanubia, three in Eastern Hungary and one in Central Hungary. Six regions include three counties each while Pest county and the capital Budapest compose Central Hungary Region. Looking at the geographical location of SFs, SSFs and COFs an interesting phenomena can be observed. The share of COFs within individual holdings is the highest in North and Eastern Hungary (North Hungary, North and South Great Plane) with highest unemployment rate and the latter two are agriculture dominated regions. The two highest shares of SSFs also belong to North and South Great Plane. People loosing their jobs in these regions were more forced to do farming for survival as job opportunities other than in agriculture has been shortage. Most of SSFs applications (83.7\%) between 2004-2006 came from Eastern Hungary and South Transdanubia regions. In the other four regions, where unemployment level in relative term has been lower the share of SFs is the highest (50-60\%).

\subsection{National policy measures for SF and SSF}

Major tool to improve farming facilities and to increase outputs of SSFs and SFs was the taxation system. Basically these farms were subject to taxation according to personal income tax rules. Below a certain level of turnover private holdings were not obliged to pay tax. SSFs and SFs are regarded as primary producers if the source of income is from selling the products produced by the SSF and SF himself/herself. Taxation of SSFs and SFs is complex and the limits on turnover and tax change from year to year but the basic philosophy of taxation left the same. A simplified version of taxation of 2007 is the following: For taxation purpose primary producer can choose (a) costs based taxation or (b) fixed tax version. Within costs based one concerning the tax of primary producer can be calculated as follows: 10 percent of total turnover is costs but no receipts for justifications were required or, the producer should use full costs record approach backed by invoices. If the total annual turnover is below HUF 600 thousands than there is no tax obligation. In case of using full costs record approach (if turnover from primary producer's activity does not access HUF 7 million) then $40 \%$ of total turnover over justified costs can be recorded as general costs without any receipt. The calculated income from primary producers' activity becomes the part of total tax base and the latter is taxed according to personnel income tax table. In case of those choosing fixed tax system $15 \%$ of turnover is regarded as tax base. If the latter comes from animal husbandry activity then tax base is $6 \%$ of total turnover. Tax is calculated on personnel income tax table.

If primary producers choose full costs record having turnover between HUF 600000 and HUF 4 million and having no other income they can submit a simplified tax 
sheet indicating not having income from primary production if having justified costs (receipts) equal minimum $20 \%$ of the turnover. The tax of total tax base can be decreased by a maximum HUF 100000 conditionally. If total annual turnover is above HUF 6 Million the tax reduction is equal to the amount above the $20 \%$ of actual turnover after deducting HUF 6 million. No tax preference can be justified if total annual income is above HUF 5,5 million. On the one side, government wanted to have small farms be registered at the tax office, but on the other side to fix tax rules in a way leaving farms interested in future farming and increasing outputs.

According to Law LXXX. 1997 (Tbj) agricultural primary producer has social security. Some exemption about paying social security fee is described in the law. Level of labour tax is the following: according to social minimum wage: $29 \%$ goes for social security fee, $7 \%$ for health care and $8.5 \%$ for pension fund. However, if total amount of turnover from primary production has not exceed HUF 7 million in previous year then $20 \%$ of actual turnover is the base and $8.5 \%$ of the latter goes to pension fund and $4 \%$ to health care fund.

According to VAT tax rules anybody running business subjects to taxation and should be registered at the tax office from January 1, 2010 on.

\subsection{Measure to support SSF' restructuring}

Providing EU (70 \%) and national support (30\%) to SSFs MoARD released three calls for restructuring SSF subsector. The calls indicated the details of measures, the goals of support and gives information on how to get a grant. The program was targeted to provide help especially those small farms suffering from lack of capital but want to change farm structure in order to establish a viable one.

Eligible agents are: primary producers, entrepreneurs engaged in agriculture and family farms.

Conditions for eligibility were as follows:

a) to have min 2 max 5 ESU in previous year to submitting application from the following activities: cultivation of arable land between 5 to $\mathbf{1 0}$ ha, or having orchard or vineyards or running greenhouse vegetable production on maximum $\mathbf{0 , 3}$ ha or having sufficient grassland for $\mathbf{2}$ to $\mathbf{1 0}$ animal units where 1,4-1,8 animal units per ha can be calculated or, from other agricultural activities.

b) to have at least a certificate of a middle level professional school or having 3 year long professional experience.

c) A business plan should be worked out for 5 years and obligation to increase the farm size by ESU by $50 \%$ in the final year in compare with that in the year prior to submitting application should be taken.

d) taking the commitment of applicants to reach ESU 5 by the end of the fifth year.

E). Application should be submitted on official forms.

\section{Results}

Holdings had the chance to apply for grant in 2004, 2005 and 2006. Grant covered 5 years with Euro 1000 in each year. Besides normal monitoring there is a check in the third year and, if farmer do not keep the conditions then the support is terminated.

According to the number of applicants it looks like that the calls were not attractive for SSF sub-sector to get a grant in order to establish a viable farming after five years. SSFs from three regions were more interested in getting the grant as North Great Plain with 440 applicants (38.6\%), South Transdanubia with 262 applicants $(23 \%)$ and South Great Plain having 252 applicants $(22,1 \%)$. All three regions are agriculture dominated ones but not homogenous. However, altogether in average less than 400 SSFs applied for grant annually. The total number of applicants amounted to 1139 that amounted to some $2-3 \%$ of total SSFs (ESU $2<5$ ). The policy with the call has reached a very moderate number of SSFs and, on the other side small farms, either because not meeting the criteria of the call or not wanted to take the additional costs of being registered and monitored for such a small amount of support decided not to apply.

Much less applications has been submitted during 20042006 than expected. So it is an important government policy goal to have more SSFs be supported in period 2007-2013 and after that.

For future policy a detailed analysis of the results of the first three calls should be made and consistency of criteria should be checked and improved for the next call. Surprisingly, number of applications for claiming payments was much less than the number of applications submitted for grants (Annex 12). The budget spent on supporting SSFs under this scheme accounted for less than EURO 2 million in 2005-2009. It amounted to annually EURO 5-600 thousands in the first two years followed by a decline in subsequent years.

\section{Discussion}

According to poor results of applications to support restructuring SSFs MoARD ordered a study to find explanation of this situation. It was underlined: the report should be based on a survey using sampling of applications. There was a need to figure out the reasons of the low number of applications and, making proposals for changing policy. In addition there was a need for a well prepared coordination and communication with other related professional organizations, lobbying groups during writing the study. It was also a goal, to take the advantage of the program as much as possible by using up all financial resources available, and the revision of the conditions applied in previous call should be given, and proposal should be initiated to extent the circle of eligible farms.

Besides the call for SSFs for restructuring farming there were possibility for SSFs to join other measures as 
supporting producers' groups, agro-environmental measures, meeting standards and technical assistance. Concerning above mentioned possibilities SSF have not been interested in organizing or joining producers' groups, and also hesitated to meeting standards and technical assistance. Those joining the agro-environmental measures were not significant. Small farms found that getting Euro 1000 annually for five years is not a big amount and in change farms should register and be ready for checking and keeping contact with tax office was not encouraging.

However, expert say that setting up conditions in a new call more fit to farmers' needs then probably some 15-20 thousand farms could be regarded to be interested in considering taking the advantage of this measure.

\section{Lessons for future policy from Hungarian experience:}

a) have a more clear vision on what farm structure the country would like to have in the future;

b) keep in mind that SF and SSF - are not only an economic units but belong to households and are also part of the social net;

c) have a state-of-art of weak results of the first three calls;

d) revise criteria for becoming eligible for the grant;

e) a good promotion on advertising the call should be carried out;

f) a better communication with SFs and SSFs on the goal and benefits of the measure is needed;

g) simplify the administrative burden for applicants as much as possible.

\section{Acknowledgments}

Previous version of this study has been prepared by having EU financial support and was discussed during the conference of ,Semi-subsistence farming in the EU: Current situation and future prospects". Sibiu, Romania, 13-15 October, 2010.

\section{References}

CSO. http://portal.ksh.hu/pls/ksh/docs/hun/xftp/idoszaki/ momg/momg07.pdf

CSO: Agricultural census, 2000.

Giurca, Daniela: Semi-Subsistence Farming - Prospects for the Small Romanian Farmer to Choose between a "Way of Living" or Efficiency.

Source: http://ideas.repec.org/a/iag/reviea/v5y2008i3-4p 215-230.html

Hegyi Judit, Kacz Károly, Kettinger Anita: A gazdaság fogalmának változása - a méretváltozás tükrében. http://www. avacongress.net/ava2007/presentations/poster/17.pdf

http://ideas.repec.org/a/iag/reviea/v5y2008i3-4p215230.html

\section{Law LXXX. 1997 (Tbj)}

MoARD: Az EMVA tervezéshez kapcsolódó 2007-2013-as időszakra vonatkozó tervdokumentumok alapjait képző, háttérszámításokat és elemzéseket, valamint javaslatokat tartalmazó tanulmány. (State of art and proposals for future actions on SSF). Manuscript.

MoARD directives /2004. (IX. 11.) FVM rendelet 